\title{
Breast Hypoplasia
}

National Cancer Institute

\section{Source}

National Cancer Institute. Breast Hypoplasia. NCI Thesaurus. Code C78222.

Underdevelopment of the breast. 